International Journal of Engineering \& Technology, $7(3.30)(2018) 208-214$
International Journal of Engineering \& Technology
WPC
Website www.sciencepubco.com/index.php/IJET
Research paper

\title{
Competencies of Indonesian Architects with Sosio Cultural Ecology: Anatomy based on Architect Background
}

\author{
Sigit Wijaksono ${ }^{1}$, Sasmoko ${ }^{2,5^{*}}$, Yasinta Indrianti ${ }^{3,5}$, Samuel Anindyo Widhoyoko ${ }^{4,5}$ \\ ${ }^{1}$ Architecture Department, Faculty of Engineering, Bina Nusantara University, Jakarta, Indonesia \\ ${ }^{2}$ Primary Teacher Education Department, Faculty of Humanities, Bina Nusantara University, Jakarta, Indonesia \\ ${ }^{3}$ Faculty of Social, Podomoro University, Jakarta, Indonesia \\ ${ }^{4}$ Accounting Department, Faculty of Social, Podomoro University, Jakarta, Indonesia \\ ${ }^{5}$ Research Interest Group in Education Technology, Bina Nusantara University, Jakarta, Indonesia \\ *Corresponding author E-mail: sasmoko@binus.edu
}

\begin{abstract}
The architect's background becomes a key factor determining its success which is reflected through the competence of the architect itself. And the diversity of architectural backgrounds provided the basis for this research. The study aims to see if there are differences in the competence of Indonesian architects if distinguished based on demographic background and architectural work, and what architect's background is the most powerful in determining its competence. A neuroresearch method is a method applied in this research. The results showed that there are differences in the competence of Indonesian architects if differentiated based on demographic background and architectural works. The second research result is the number of projects handled by Architects is a very decisive variable to realize the Indonesian architects become more competent.
\end{abstract}

Keywords: Competencies of Indonesian Architects, Sosio Cultural Ecology.

\section{Introduction}

For architects, designing a corporate project is a milestone capable of raising the name of the architectural consulting firm or lifting the name of the architect himself. Because corporate projects are usually of high value on a large scale and involve multiple stakeholders with different goals and needs. And this field continues to evolve as it requires an increase in professionalism and transformation from the architect itself $[1,2]$. The scheme of globalization used in the field of architecture refers to a series of rich and complex interpretations that highlight the importance of architecture, institutions and the work itself [3]

In the project, there is usually a conflict of interest between the architect and in the company who provided the project. The difference of interest is usually from the aspect that the project owner always has corporate goals, while the architect has professional goals. In the Czech Republic, a study attempts to illustrate the role of enterprise architect with a broad spectrum of knowledge and skills that leads to the importance of educating these experts with the necessary requirements to perform the role of the architect [4]. This is where the architect's background becomes a key factor in determining its success which is illustrated through the competence of the architect itself, especially in developing the architect of Jakarta Socio-Cultural Ecology, the architectural concept that collaborates between social life, culture and ecology [5]. Competence is the ability to implement a set of knowledge, skills, and ability to do the work so that it can be completed properly [6]. This can arise because of many reasons, among others: (1) the architect does not understand the interests of the owner, (2) the architect does not succeed in presenting the design concept that can be understood by the owner, and (3) the architect is weak in terms of project supervision. Some experience in the field says that often the knowledge of the architect is not easily manifested in practice [7].

For the owner, using the services of an architect in the execution of a project can provide added-value to the built works. Architects have the ability to compose space programs, needs, and problems into high-value architectural works. The general problem solving, and complexity of management strategies becomes one of the most important competencies an architect should possess [8].

Therefore, it is very important for the architect to study the client's interest from the beginning of the design so that the design made not only answers the architect's vision in person but answers the owner's objectives as closely as possible. Because client satisfaction evaluation becomes one of the successes in architectural projects [9]. The key factor is on the architect's own background. The problems studied are: (1) is there any difference in the competence of Indonesian architects, if distinguished based on demographic background and architectural work?, and (2) what architect background determines the most competence?

\section{Research Method}

This research uses one type of mixed method developed in Indonesia that is Neuroresearch method. This method begins with a stage called exploratory research in which the researcher will conduct explorative studies on various related studies so as to find theoretical constructs that fit the concept of research [10]. The next two stages are called explanatory research and confirmatory research which are more quantitative in order to arrive at instrument validity and hypothesis verification. This qualitative and 
quantitative incorporation makes this research included in research mixed methods $[11,12,13]$.

The research instrument has a demographic picture of gender, age, educational background, certification participation, college status, educational origin, work experience abroad, ownership of consulting firm, experience as architect, number of projects handled, type of building designation, building ownership, and the number of storeys of the building.

\section{Result}

\subsection{Result of First Hypothesis}

To find out whether there are differences in the competence of Indonesian architects, if differentiated based on the architect's background, include: Analysis of differences in the Competence of Indonesian Architects (Y) if differentiated by Sex (Sex_X1).

The homogeneity test with Levene produced $F$ of 0.425 with a significance value of 0.516 is non-significance at $\alpha>0.05$. That is, variance male architects with women proved homogeneous (equal variances assumed). Based on homogeneity test resulted $\mathrm{t}$ value equal to 1,733 with significance value equal to 0,087 is nonsignificance at $\alpha>0,05$. Thus, there is no difference in the Competence of Indonesian Architects (Y) if differentiated by sex (Sex$\mathrm{X} 1$ ). That is, architects of male sex with women proved equally competent significantly at $\alpha<0.05$.

\begin{tabular}{|c|c|c|c|c|c|}
\hline & Sex-X1 & $\mathrm{N}$ & Mean & Std. Deviation & $\begin{array}{c}\text { Std. Error } \\
\text { Mean }\end{array}$ \\
\hline Competence_r & $\begin{array}{l}\text { Male } \\
\text { Female }\end{array}$ & $\begin{array}{r}81 \\
4\end{array}$ & $\begin{array}{l}349.7407 \\
327.5000\end{array}$ & $\begin{array}{l}25.30108 \\
17.17556\end{array}$ & $\begin{array}{l}2.81123 \\
8.58778\end{array}$ \\
\hline
\end{tabular}

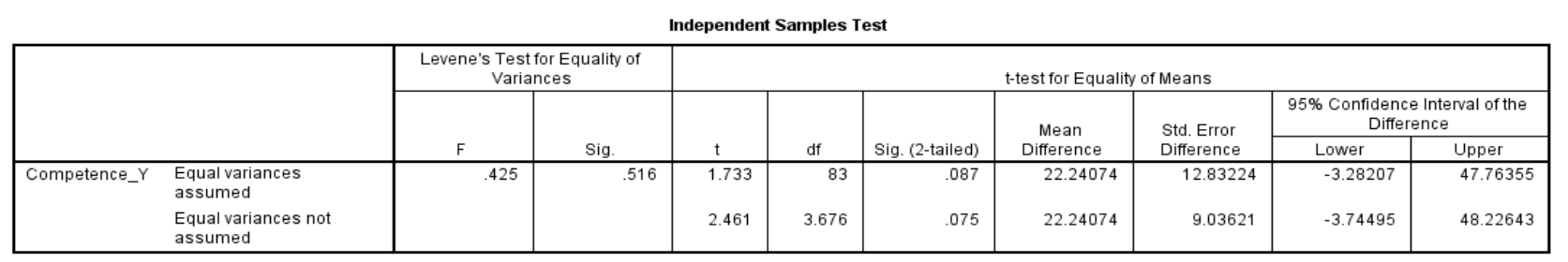

Analysis of differences in Competence of Indonesian Architects (Y) if differentiated by Age (Age-X2). The proof is done by One Way of Anova which yields $\mathrm{F}$ of 2,373 with significance value of 0.076 is non-significant at $\alpha>0,05$. So, there is no difference in the Competence of Indonesian Architects (Y) if differentiated by Age (Age-X2). That is, Indonesian architects $<30$ years old or 3040 years old or 41-50 years old or $>50$ years are all equally competent significantly on $\alpha<0.05$.

Descriptives

\begin{tabular}{|c|c|c|c|c|c|c|c|c|}
\hline & \multirow[b]{2}{*}{$\mathrm{N}$} & \multirow[b]{2}{*}{ Mean } & \multirow[b]{2}{*}{ Std. Deviation } & \multirow[b]{2}{*}{ Std. Error } & \multicolumn{2}{|c|}{$\begin{array}{l}95 \% \text { Confidence Interval for } \\
\text { Mean }\end{array}$} & \multirow[b]{2}{*}{ Minimum } & \multirow[b]{2}{*}{ Maximum } \\
\hline & & & & & Lower Bound & Upper Bound & & \\
\hline$<30$ years & 17 & 344.4706 & 27.98687 & 6.78781 & 330.0811 & 358.8601 & 253.00 & 385.00 \\
\hline $30-40$ years & 37 & 348.4324 & 26.38343 & 4.33741 & 339.6358 & 357.2291 & 278.00 & 400.00 \\
\hline $41-50$ years & 28 & 347.6786 & 20.46144 & 3.86685 & 339.7445 & 355.6127 & 300.00 & 393.00 \\
\hline$>50$ years & 3 & 385.3333 & 19.03506 & 10.98989 & 338.0476 & 432.6190 & 367.00 & 405.00 \\
\hline Total & 85 & 348.6941 & 25.35041 & 2.74964 & 343.2262 & 354.1621 & 253.00 & 405.00 \\
\hline
\end{tabular}

ANOVA

Competence_Y
\begin{tabular}{|l|c|r|r|r|c|}
\hline & Sum of & df & Mean Square & F & Sig. \\
\hline Between Groups & 4361.957 & 3 & 1453.986 & 2.373 & .076 \\
Within Groups & 49620.090 & 81 & 612.594 & & \\
Total & 53982.047 & 84 & & & \\
\hline
\end{tabular}

Analysis of differences in Competence of Indonesian Architects (Y) if differentiated based on Background Education (S1, S2 and S3). The proof is done with One Way of Anova which yields F equal to 1,249 with significance value of 0.292 is non-significant at $\alpha>0,05$. So there is no difference Competence of Indonesian
Architects (Y) if differentiated based on Background Education (S1, S2 and S3). That is, the architects of Indonesia who are aged educational background $\mathrm{S} 1$ or $\mathrm{S} 2$ or S3 are all equally competent significantly on $\alpha<0.05$.

Descriptives

Competence_Y

\begin{tabular}{|c|c|c|c|c|c|c|c|c|}
\hline & \multirow[b]{2}{*}{$N$} & \multirow[b]{2}{*}{ Mean } & \multirow[b]{2}{*}{ Std. Deviation } & \multirow[b]{2}{*}{ Std. Error } & \multicolumn{2}{|c|}{$\begin{array}{l}95 \% \text { Confidence Interval for } \\
\text { Mean }\end{array}$} & \multirow[b]{2}{*}{ Minimum } & \multirow[b]{2}{*}{ Maximum } \\
\hline & & & & & Lower Bound & Upper Bound & & \\
\hline S1 & 50 & 346.9200 & 28.13803 & 3.97932 & 338.9233 & 354.9167 & 253.00 & 405.00 \\
\hline$S 2$ & 32 & 353.0313 & 20.28584 & 3.58606 & 345.7174 & 360.3451 & 300.00 & 393.00 \\
\hline S3 & 3 & 332.0000 & 20.42058 & 11.78983 & 281.2725 & 382.7275 & 316.00 & 355.00 \\
\hline Total & 85 & 348.6941 & 25.35041 & 2.74964 & 343.2262 & 354.1621 & 253.00 & 405.00 \\
\hline
\end{tabular}


ANOVA

Competence $Y$

\begin{tabular}{|l|c|r|r|c|c|} 
& $\begin{array}{c}\text { Sum of } \\
\text { Squares }\end{array}$ & df & Mean Square & F & Sig. \\
\hline Between Groups & 1595.398 & 2 & 797.699 & 1.249 & .292 \\
Within Groups & 52386.649 & 82 & 638.862 & \\
Total & 53982.047 & 84 & & \\
\hline
\end{tabular}

Analysis of differences in Competence of Indonesian Architects (Y) if differentiated by Certification Entry (Certificate_X4). Homogeneity test with Levene yielded $\mathrm{F}$ of 0.066 with significance value of 0.798 is non-significance at $\alpha>0.05$. That is, the variance of architects who have been certified as well as unproven homogeneous (equal variances assumed). Based on the homogeneity test resulted in t value equal to 2,887 with significance value equal to 0,005 the is significance at $\alpha<0,05$. Thus, there is a difference in the Competence of Indonesian Architects (Y) if differentiated by Certification Entry (Certificate_X4). That is, architects who have been certified (Already) tend to be competent, while those that have not been certified are competent enough significantly at $\alpha<0.05$.

Group Statistics

\begin{tabular}{|c|c|c|c|c|c|}
\hline & Certification $\times 4$ & $\mathrm{~N}$ & Mean & Std. Deviation & $\begin{array}{c}\text { Std. Error } \\
\text { Mean }\end{array}$ \\
\hline \multirow[t]{2}{*}{ Competence_r } & Already & 68 & 352.5000 & 24.13117 & 2.92633 \\
\hline & Not Yet & 17 & 333.4706 & 25.05274 & 6.07618 \\
\hline
\end{tabular}

\begin{tabular}{|c|c|c|c|c|c|c|c|c|c|c|}
\hline \multicolumn{11}{|c|}{ Independent Samples Test } \\
\hline & & \multicolumn{2}{|c|}{$\begin{array}{l}\text { Levene's Test for Equality of } \\
\text { Variances }\end{array}$} & \multicolumn{7}{|c|}{ t-test for Equality of Means } \\
\hline & & \multirow[b]{2}{*}{$F$} & \multirow[b]{2}{*}{ Sig. } & \multirow[b]{2}{*}{$t$} & \multirow[b]{2}{*}{ df } & \multirow[b]{2}{*}{ Sig. (2-tailed) } & \multirow{2}{*}{$\begin{array}{c}\text { Mean } \\
\text { Difference }\end{array}$} & \multirow{2}{*}{$\begin{array}{l}\text { Std. Error } \\
\text { Difference }\end{array}$} & \multicolumn{2}{|c|}{$\begin{array}{l}\text { 95\% Confidence Interval of the } \\
\text { Difference }\end{array}$} \\
\hline & & & & & & & & & Lower & Upper \\
\hline \multirow[t]{2}{*}{ Competence_Y } & $\begin{array}{l}\text { Equal variances } \\
\text { assumed }\end{array}$ & .066 & .798 & 2.887 & 83 & .005 & 19.02941 & 6.59239 & 5.91741 & 32.14141 \\
\hline & $\begin{array}{l}\text { Equal variances not } \\
\text { assumed }\end{array}$ & & & 2.822 & 23.975 & .009 & 19.02941 & 6.74414 & 5.10942 & $32.9494 c$ \\
\hline
\end{tabular}

Analysis of differences in the Competence of Indonesian Architects $(\mathrm{Y})$ if differentiated by the status of public or private universities (HE_X5). The homogeneity test with Levene yielded $\mathrm{F}$ of 20,921 with a significance value of 0,000 is very significance at $\alpha$ $<0,01$. That is, the variance of architects who come from public universities (public) and private (private) proved to be heterogeneous (equal variances not assumed). Based on homogeneity test resulted $\mathrm{t}$ value equal to 0,556 with significance value equal to 0,584 is non-significance at $\alpha>0,05$. Thus, there is no difference in the Competence of Indonesian Architects (Y) if differentiated by the Status of Higher Education (HE_X5). That is, the architects of state college graduates with private proved equally competent significantly on $\alpha<0.05$.
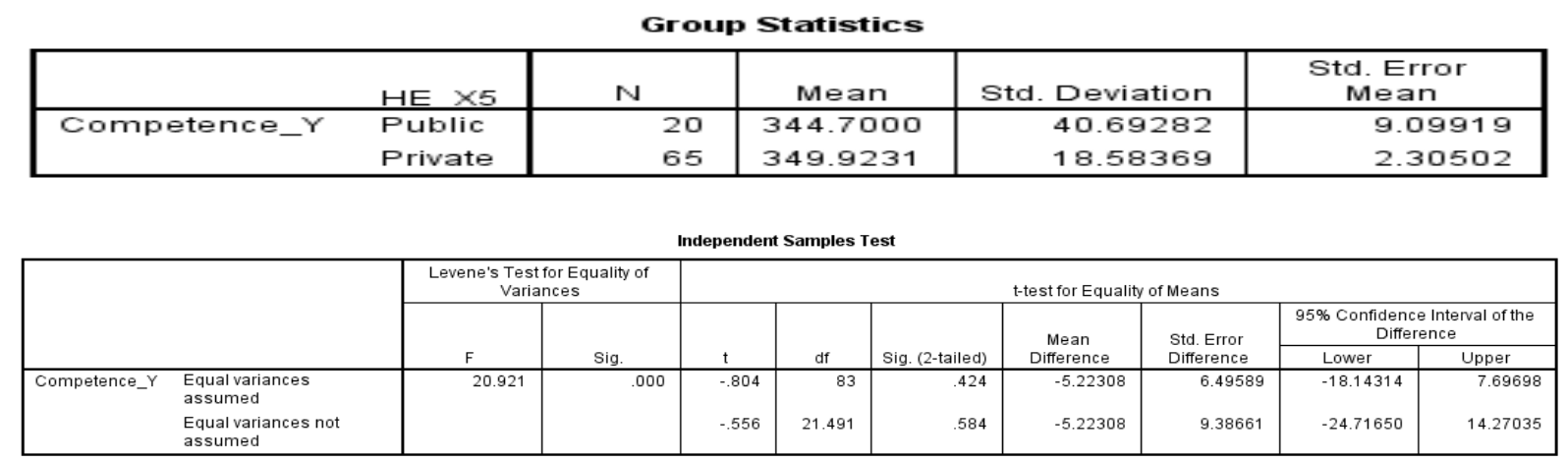

Analysis of differences in the Competence of Indonesian Architects (Y) if differentiated by the origin of education both from foreign and domestic school (Educ_Country_X6). The homogeneity test with Levene produced $\mathrm{F}$ of 3,197 with significance value of 0.077 is non-significance at $\alpha>0,05$. This means that the variance of architects from overseas and domestic universities proves to be homogeneous (equal variances assumed). Based on homoge- neity test resulted t value equal to 0,956 with significance value equal to 0,342 is non-significance at $\alpha>0,05$. So, there is no difference in the Competence of Indonesian Architects (Y) if differentiated based on the origin of colleges both abroad and within the country (Educ_Country_X6). That is, the architects of overseas and domestic graduates proved equally competent significantly on $\alpha<0.05$.

Group Statistics

\begin{tabular}{|ll|r|r|r|r|}
\hline & & & & & \multicolumn{1}{c|}{$\begin{array}{c}\text { Std. Error } \\
\text { Mean }\end{array}$} \\
\hline Competence_Y & Overseas & Mean & Std. Deviation & 3.65679 \\
& Domestic & 21 & 353.2857 & 16.75751 & 3.44233 \\
\hline
\end{tabular}




\begin{tabular}{|c|c|c|c|c|c|c|c|c|c|c|}
\hline \multicolumn{11}{|c|}{ Independent Samples Test } \\
\hline & & \multicolumn{2}{|c|}{$\begin{array}{l}\text { Levene's Test for Equality of } \\
\text { Variances }\end{array}$} & \multicolumn{7}{|c|}{ t-test for Equality of Means } \\
\hline & & \multirow[b]{2}{*}{$\mathrm{F}$} & \multirow[b]{2}{*}{ Sig. } & \multirow[b]{2}{*}{$t$} & \multirow[b]{2}{*}{ df } & \multirow[b]{2}{*}{ Sig. (2-tailed) } & \multirow{2}{*}{$\begin{array}{c}\text { Mean } \\
\text { Difference }\end{array}$} & \multirow{2}{*}{$\begin{array}{l}\text { Std. Error } \\
\text { Difference }\end{array}$} & \multicolumn{2}{|c|}{$\begin{array}{l}95 \% \text { Confidence Interval of the } \\
\text { Difference }\end{array}$} \\
\hline & & & & & & & & & Lower & Upper \\
\hline$\overline{\text { Competence_Y }}$ & $\begin{array}{l}\text { Equal variances } \\
\text { assumed }\end{array}$ & 3.197 & .077 & .956 & 83 & .342 & 6.09821 & 6.37848 & -6.58832 & 18.78475 \\
\hline & $\begin{array}{l}\text { Equal variances not } \\
\text { assumed }\end{array}$ & & & 1.214 & 56.953 & .230 & 6.09821 & 5.02213 & -3.95860 & 16.15503 \\
\hline
\end{tabular}

Analysis of differences in Competence of Indonesian Architects (Y) if differentiated by Ownership of Consultant Company (Company_X7). The proof is done by One Way of Anova which yields an $\mathrm{F}$ of 0.927 with the significance value of 0.400 is nonsignificant at $\alpha>0.05$. So, there is no difference in the Compe- tence of Indonesian Architects (Y) if differentiated by Ownership of Consultant Company (Company_X7). That is, the architects of Indonesia whose status as the owner of the company or only staff companies or independent architects not under the company proved all equally competent significantly on $\alpha<0.05$.

Descriptives

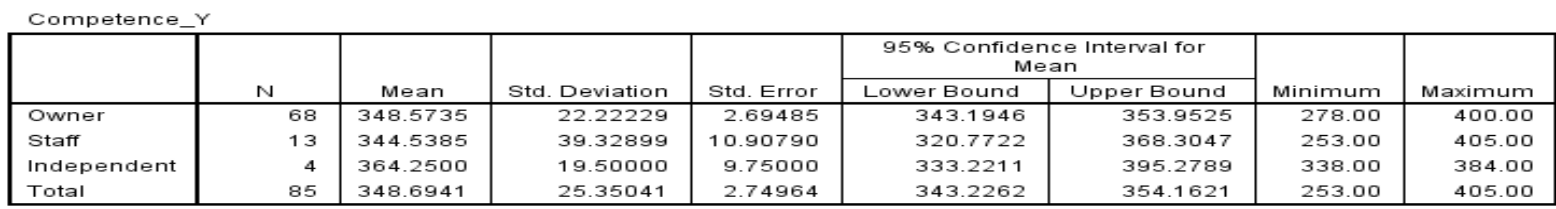

ANONA

Competence_r
\begin{tabular}{|l|c|r|r|r|r|}
\hline & Sum of & df & Mean Square & F & Sig. \\
\hline Between Groups & 1193.434 & 2 & 596.717 & .927 & .400 \\
Within Groups & 52788.613 & 82 & 643.764 & & \\
Total & 53982.047 & 84 & & \\
\hline
\end{tabular}

Analysis of differences in the Competence of Indonesian Architects (Y) if differentiated by whether the architect has ever worked abroad (Working_X8). The homogeneity test with Levene produced $F$ equal to 1.372 with the significance value of 0.245 is nonsignificance at $\alpha>0,05$. That is, the variance of architects who have worked abroad (ever) and who have never (never) proven homogeneous (equal variances assumed). Based on homogeneity test resulted $\mathrm{t}$ value equal to 1,408 with significance value equal to 0,163 is non-significance at $\alpha>0,05$. Thus, there is no difference in the Competence of Indonesian Architects (Y) if differentiated by whether or not the architect has ever worked abroad (Working_X8). That is architects who had worked abroad and who have never proved equally competent significantly on $\alpha<0.05$.

\begin{tabular}{|ll|r|r|r|r|}
\hline & Group Statistics \\
& Working $\times 8$ & $\mathrm{~N}$ & Mean & Std. Deviation & $\begin{array}{c}\text { Std. Error } \\
\text { Mean }\end{array}$ \\
\hline Competence_Y & Ever & 16 & 356.6875 & 17.70016 & 4.42504 \\
& Never & 69 & 346.8406 & 26.57488 & 3.19924 \\
\hline
\end{tabular}

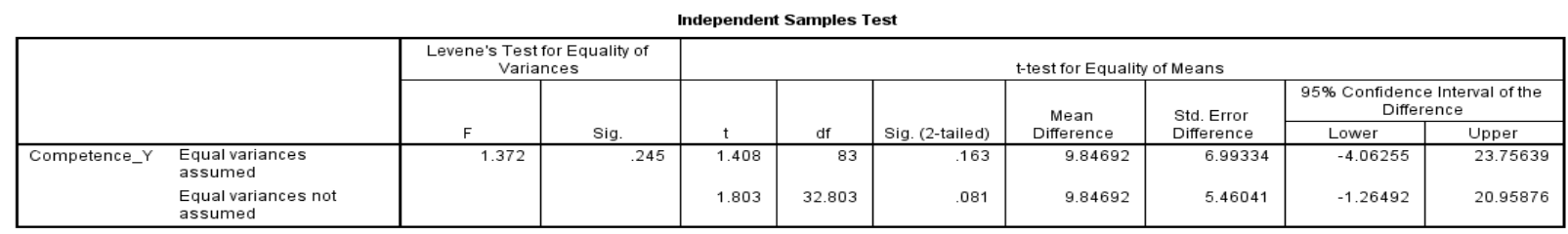

Analysis of differences in Competence of Indonesian Architects (Y) if differentiated by work experience to be an architect (Experience_X9). The proof is done by One Way of Anova which yields $F$ of 0,503 with a significance value of 0.681 is non-significant at $\alpha>0,05$. So, there is no difference Indonesian Architects Compe- tencies (Y) if distinguished by work experience to be an architect (Experience_X9). That is, Indonesian architects who have working experience $<5$ years or 5-10 years or 11-20 years or $>20$ years proved all equally competent significantly on $\alpha<0.05$.

\section{Descriptives}

Competence $Y$

\begin{tabular}{|c|c|c|c|c|c|c|c|c|}
\hline & \multirow[b]{2}{*}{$\mathrm{N}$} & \multirow[b]{2}{*}{ Mean } & \multirow[b]{2}{*}{ Std. Deviation } & \multirow[b]{2}{*}{ Std. Error } & \multicolumn{2}{|c|}{$\begin{array}{l}\text { 95\% Confidence Interval for } \\
\text { Mean }\end{array}$} & \multirow[b]{2}{*}{ Minimum } & \multirow[b]{2}{*}{ Maximum } \\
\hline & & & & & Lower Bound & Upper Bound & & \\
\hline $5-10$ years & 22 & 343.7273 & 27.66669 & 5.89856 & 331.4605 & 355.9940 & 253.00 & 376.00 \\
\hline $11-20$ years & 36 & 350.8889 & 27.56994 & 4.59499 & 341.5606 & 360.2172 & 278.00 & 400.00 \\
\hline$>20$ years & 15 & 352.4667 & 23.58833 & 6.09048 & 339.4039 & 365.5295 & 323.00 & 405.00 \\
\hline
\end{tabular}


ANONA

\begin{tabular}{|l|c|r|r|r|r|}
\hline & Sum of & df & Mean Square & F & Sig. \\
\hline Between Groups & 987.395 & 3 & 329.132 & .503 & .681 \\
Within Groups & 52994.653 & 81 & 654.255 & & \\
Total & 53982.047 & 84 & & & \\
\hline
\end{tabular}

Analysis of differences in Competence of Indonesian Architects (Y) if differentiated based on number of projects ever handled (Project_X10). The proof is done with One Way of Anova which yields $\mathrm{F}$ of 5,370 with significance value of 0,002 is significant at $\alpha<0,05$. So, there is a difference in Competence of Indonesian
Architects (Y) if differentiated based on the number of projects ever handled (Project_X10). Architects who are considered competent if the person has handled $<5$ projects or above 11 projects significantly on $\alpha<0.05$ than the architect who handles between 5 10 projects.

Descriptives

\begin{tabular}{|c|c|c|c|c|c|c|c|c|}
\hline & \multirow[b]{2}{*}{$\mathrm{N}$} & \multirow[b]{2}{*}{ Mean } & \multirow[b]{2}{*}{ Deviation } & \multirow[b]{2}{*}{ Std. Error } & \multicolumn{2}{|c|}{$\begin{array}{l}95 \% \text { Confidence Interval for } \\
\text { Mean }\end{array}$} & \multirow[b]{2}{*}{ Minimum } & \multirow[b]{2}{*}{ Maximum } \\
\hline & & & & & Lower Bound & Upper Bound & & \\
\hline$<5$ projects & 4 & 347.7500 & 18.83923 & 9.41962 & 317.7726 & 377.7274 & 338.00 & 376.00 \\
\hline 5-10 projects & 3 & 299.0000 & 45.50824 & 26.27420 & 185.9513 & 412.0487 & 253.00 & 344.00 \\
\hline $11-20$ projects & 18 & 357.9444 & 19.56429 & 4.61135 & 348.2154 & 367.6735 & 316.00 & 388.00 \\
\hline >20 projects & 60 & 348.4667 & 23.76186 & 3.06764 & 342.3283 & 354.6050 & 278.00 & 405.00 \\
\hline Total & 85 & 348.6941 & 25.35041 & 2.74964 & 343.2262 & 354.1621 & 253.00 & 405.00 \\
\hline
\end{tabular}

ANONA

Competence_r

\begin{tabular}{|l|r|r|r|r|}
\hline & Sum of & df & Mean Square & F \\
\hline Setween Groups & 8955.419 & 3 & 2985.140 & 5.370 \\
Within Groups & 45026.628 & 81 & 555.884 & \\
Total & 53982.047 & 84 & & \\
\hline
\end{tabular}

Multiple Comparisons

Dependent Variable: Competence_Y LSD

\begin{tabular}{|c|c|c|c|c|c|c|}
\hline \multirow[b]{2}{*}{ (I) Project $\times 10$} & \multirow[b]{2}{*}{ (J) Project $\times 10$} & \multirow{2}{*}{$\begin{array}{c}\text { Mean } \\
\text { Difference (I- } \\
\mathrm{J})\end{array}$} & \multirow[b]{2}{*}{ Std. Error } & \multirow[b]{2}{*}{ Sig. } & \multicolumn{2}{|c|}{$95 \%$ Confidence Interval } \\
\hline & & & & & Lower Bound & Upper Bound \\
\hline \multirow[t]{3}{*}{$<5$ projects } & $5-10$ projects & $48.75000^{\prime \prime}$ & 18.00738 & .008 & 12.9210 & 84.5790 \\
\hline & $11-20$ projects & -10.19444 & 13.03279 & .436 & -36.1256 & 15.7367 \\
\hline & $>20$ projects & -.71667 & 12.17521 & .953 & -24.9415 & 23.5082 \\
\hline \multirow[t]{3}{*}{ 5-10 projects } & $<5$ projects & $-48.75000^{n}$ & 18.00738 & .008 & -84.5790 & -12.9210 \\
\hline & $11-20$ projects & $-58.94444^{\star}$ & 14.70297 & .000 & -88.1987 & -29.6902 \\
\hline & $>20$ projects & $-49.46667^{*}$ & 13.94846 & .001 & -77.2197 & -21.7136 \\
\hline \multirow[t]{3}{*}{$11-20$ projects } & $<5$ projects & 10.19444 & 13.03279 & .436 & -15.7367 & 36.1256 \\
\hline & $5-10$ projects & $58.94444^{\star}$ & 14.70297 & .000 & 29.6902 & 88.1987 \\
\hline & $>20$ projects & 9.47778 & 6.33618 & .139 & -3.1292 & 22.0848 \\
\hline \multirow[t]{3}{*}{$>20$ projects } & $<5$ projects & .71667 & 12.17521 & .953 & -23.5082 & 24.9415 \\
\hline & $5-10$ projects & $49.46667^{\star}$ & 13.94846 & .001 & 21.7136 & 77.2197 \\
\hline & 11-20 projects & -9.47778 & 6.33618 & .139 & -22.0848 & 3.1292 \\
\hline
\end{tabular}

*. The mean difference is significant at the 0.05 level.

Analysis of differences in Competence of Indonesian Architects (Y) if differentiated by type e of the designation of buildings (Building_X11). The proof is done with One Way of Anova which yields an $\mathrm{F}$ of 0.290 with the significance value of 0.749 is nonsignificant at $\alpha>0.05$. So there is no difference Indonesian Archi- tects Competencies (Y) if differentiated by type of allotment of buildings (Building_X11). Architects who handle general or residential or health type or educational or governmental buildings or rituals or transport buildings have proved equally competent significantly at $\alpha<0.05$.

\section{Descriptives}

Competence_Y

\begin{tabular}{|c|c|c|c|c|c|c|c|c|}
\hline & \multirow[b]{2}{*}{$\mathrm{N}$} & \multirow[b]{2}{*}{ Mean } & \multirow[b]{2}{*}{ Std. Deviation } & \multirow[b]{2}{*}{ Std. Error } & \multicolumn{2}{|c|}{$\begin{array}{l}95 \% \text { Confidence Interval for } \\
\text { Mean }\end{array}$} & \multirow[b]{2}{*}{ Minimum } & \multirow[b]{2}{*}{ Maximum } \\
\hline & & & & & Lower Bound & Upper Bound & & \\
\hline Public & 21 & 352.3810 & 21.67135 & 4.72908 & 342.5163 & 362.2456 & 320.00 & 405.00 \\
\hline Home & 61 & 347.4918 & 27.10143 & 3.46998 & 340.5508 & 354.4328 & 253.00 & 400.00 \\
\hline Health & 3 & 347.3333 & 8.38650 & 4.84195 & 326.5001 & 368.1665 & 342.00 & 357.00 \\
\hline Total & 85 & 348.6941 & 25.35041 & 2.74964 & 343.2262 & 354.1621 & 253.00 & 405.00 \\
\hline
\end{tabular}


ANONA

Competence_r
\begin{tabular}{|l|c|r|r|r|r|}
\hline & Sum of & df & Mean Square & F & Sig. \\
\hline Setween Groups & 379.182 & 2 & 189.591 & .290 & .749 \\
Within Groups & 53602.865 & 82 & 653.693 & & \\
Total & 53982.047 & 84 & & & \\
\hline
\end{tabular}

Analysis of differences in Competence of Indonesian Architects (Y) if differentiated by building ownership (Owner_X12). The proof is done with One Way of Anova which yields F of 3,631 with significance value equal to 0,031 is significant at $\alpha<0,05$. So there is difference Architects Indonesia Competencies (Y) if dif- ferentiated by building ownership (Owner_X12). That is, the Indonesian architects who handle the project of private (private) proved more competent than the architect who handles government projects (government) significantly on $\alpha<0.05$.

Descriptives

\begin{tabular}{|c|c|c|c|c|c|c|c|c|}
\hline & \multirow[b]{2}{*}{$\mathrm{N}$} & \multirow[b]{2}{*}{ Mean } & \multirow[b]{2}{*}{ Std. Deviation } & \multirow[b]{2}{*}{ Std. Error } & \multicolumn{2}{|c|}{$\begin{array}{l}95 \% \text { Confidence Interval for } \\
\text { Mean }\end{array}$} & \multirow[b]{2}{*}{ Minimum } & \multirow[b]{2}{*}{ Maximum } \\
\hline & & & & & Lower Bound & Upper Bound & & \\
\hline Goverment & 4 & 317.0000 & 42.66927 & 21.33464 & 249.1037 & 384.8963 & 253.00 & 339.00 \\
\hline Private & 79 & 350.4937 & 23.78045 & 2.67551 & 345.1671 & 355.8202 & 278.00 & 405.00 \\
\hline Foreign & 2 & 341.0000 & 4.24264 & 3.00000 & 302.8814 & 379.1186 & 338.00 & 344.00 \\
\hline Total & 85 & 348.6941 & 25.35041 & 2.74964 & 343.2262 & 354.1621 & 253.00 & 405.00 \\
\hline
\end{tabular}

ANOWA

Competence_Y
\begin{tabular}{|l|r|r|r|r|r|}
\hline & Sum of & df & Mean Square & F & Sig. \\
\hline Between Groups & 4392.300 & 2 & 2196.150 & 3.631 & .031 \\
Within Groups & 49589.747 & 82 & 604.753 & & \\
Total & 53982.047 & 84 & & \\
\hline
\end{tabular}

\begin{tabular}{|c|c|c|c|c|c|c|}
\hline \multicolumn{7}{|c|}{ Multiple Comparisons } \\
\hline \multirow[b]{2}{*}{ (1) Owner $\times 12$} & \multirow[b]{2}{*}{ (J) Owner $\times 12$} & \multirow{2}{*}{$\begin{array}{c}\text { Mean } \\
\text { Difference (I- } \\
\mathrm{J}) \\
\end{array}$} & \multirow[b]{2}{*}{ Std. Error } & \multirow[b]{2}{*}{ Sig. } & \multicolumn{2}{|c|}{$95 \%$ Confidence Interval } \\
\hline & & & & & Lower Bound & Upper Bound \\
\hline \multirow[t]{2}{*}{ Goverment } & Private & -33.49367 & 12.60331 & .009 & -58.5657 & -8.4217 \\
\hline & Foreign & -24.00000 & 21.29706 & .263 & -66.3666 & 18.3666 \\
\hline \multirow[t]{2}{*}{ Private } & Goverment & $33.49367^{n}$ & 12.60331 & .009 & 8.4217 & 58.5657 \\
\hline & Foreign & 9.49367 & 17.60771 & .591 & -25.5337 & 44.5210 \\
\hline \multirow[t]{2}{*}{ Foreign } & Goverment & 24.00000 & 21.29706 & .263 & -18.3666 & 66.3666 \\
\hline & Private & -9.49367 & 17.60771 & .591 & -44.5210 & 25.5337 \\
\hline
\end{tabular}

*. The mean difference is significant at the 0.05 level.

Analysis of differences in Competence of Indonesian Architects (Y) if differentiated based on the number of building floors (No_Floors_X13). The proof is done with One Way of Anova which yields $F$ of 1,720 with a significance value of 0.186 is nonsignificant at $\alpha>0,05$. So, there is no difference in the Compe- tence of Indonesian Architects (Y) if differentiated based on the number of building floors (No_Floors_X13). That is, Indonesian architects who handle buildings $<8$ floors or 8-20 floors or $>20$ floors proved equally competent significantly at $\alpha<0.05$.

\begin{tabular}{|c|c|c|c|c|c|c|c|c|}
\hline \multicolumn{9}{|c|}{ Descriptives } \\
\hline \\
\hline & \multirow[b]{2}{*}{$\mathrm{N}$} & \multirow[b]{2}{*}{ Mean } & \multirow[b]{2}{*}{ Std. Deviation } & \multirow[b]{2}{*}{ Std. Error } & \multicolumn{2}{|c|}{$\begin{array}{c}95 \% \text { Confidence Interval for } \\
\text { Mean }\end{array}$} & \multirow[b]{2}{*}{ Minimum } & \multirow[b]{2}{*}{ Maximum } \\
\hline & & & & & Lower Bound & Upper Bound & & \\
\hline$<8$ floors & 79 & 347.6329 & 24.28526 & 2.73231 & 342.1933 & 353.0725 & 253.00 & 400.00 \\
\hline 8-20 floors & 3 & 350.3333 & 44.41096 & 25.64068 & 240.0104 & 460.6563 & 300.00 & 384.00 \\
\hline$>20$ floors & 3 & 375.0000 & 30.51229 & 17.61628 & 299.2033 & 450.7967 & 344.00 & 405.00 \\
\hline Total & 85 & 348.6941 & 25.35041 & 2.74964 & 343.2262 & 354.1621 & 253.00 & 405.00 \\
\hline
\end{tabular}

ANOVA
Competence_r
\begin{tabular}{|l|r|r|r|r|r|}
\hline & Sum of & df & Mean Square & F \\
\hline Between Groups & 2173.026 & 2 & 1086.513 & 1.720 & Sig. \\
Within Groups & 51809.021 & 82 & 631.817 & \\
Total & 53982.047 & 84 & & \\
\hline
\end{tabular}

\subsection{Result of Second Hypothesis}

To find the architect's most decisive background in realizing the competence of Indonesian architects. The proof analyzed by this analytical approach is determined by Binary Segmentation called Classification and Regression Trees. In this analysis, the researchers set the Prunning of Depth by 2; Parent of 2; and Child of 1, with significance level $\alpha<0,05$. The results of this analysis prove that the Number of Projects Handled Architects (Project_X10) is a 
very decisive variable to realize the Indonesian architects into competence (Y). If architects focus on the number of projects handled, then the competence of Indonesian architects will increase 90.348 times from the current conditions. Increased ability to handle the number of projects is largely determined by experience (Experience_X9) which contributed 37,341 times and also due to the planned number of floors (No_Floors_X13) contributing 52.216 times from the current condition.

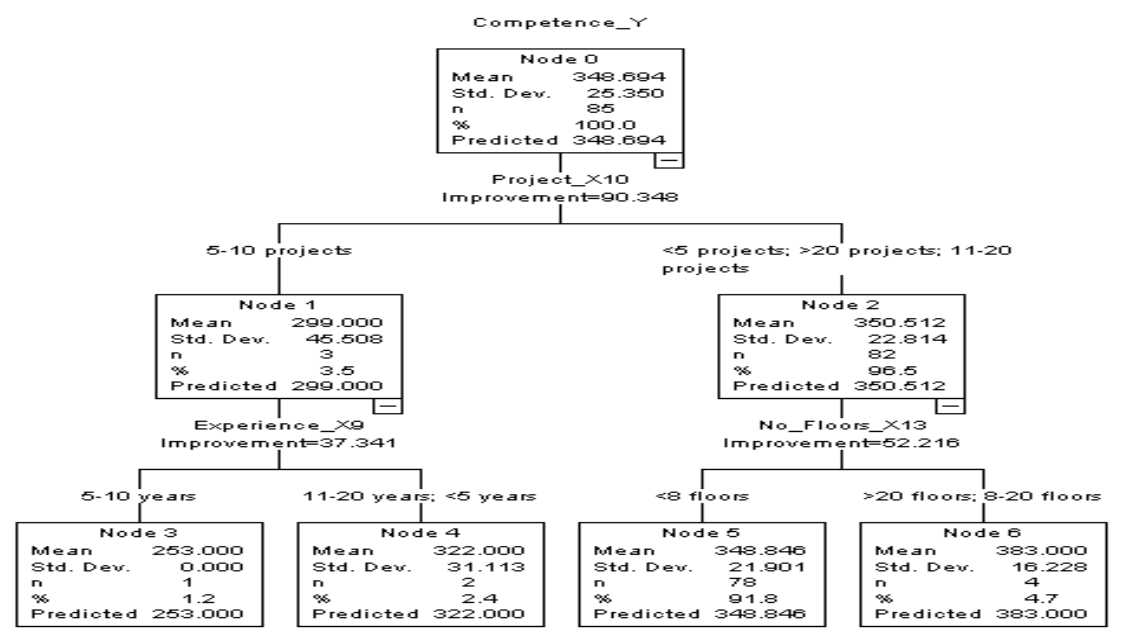

Fig. 1: Results Classification and Regression Trees against Background Architect Determinants (X1 to X13) against the Realization of Competence Architects Indonesia (Y)

\section{Conclusion and Recommendations}

Results of the study indicate the existence of various background conditions that determine the difference in the competence of the architect itself. A study even found a correlation between one's characteristics and personality to character design and architecture in general [14]. The results of the further research indicate that the number of projects handled by architects is also a factor determining the competence of Indonesian architects. For most organizations, competence has become a common thread connecting all practices and strategies together to achieve organizational performance [15]. So, building the competence for Indonesian architects becomes a very important thing to continue to be developed and cannot be delayed much longer.

\section{References}

[1] Besker T, Olsson R \& Pessi K (2015), The Enterprise Architect profession: An empirical study. In ECIME2015-9th European Conference on IS Management and Evaluation: ECIME 2015, 2122.

[2] Kumwenda M \& Sciences N (2017), Enterprise Architect Roles and Competencies Within Medium to Large Scale Organizations.

[3] Tran B (2017), The Architect of Organizational Psychology: The Geert Hofstede's Dimensions of Cultural (Corporate and Organizational) Identity. In Cultural Influences on Architecture (pp 231-258). IGI Global.

[4] Strielkowski W, Abrhám J \& Herget J (2014), Success factors of growth and development for small and medium enterprises in tourism sector. Journal of Applied Economic Sciences 9(1), 101109.

[5] Wijaksono S, Sasmoko, Indrianti Y \& Widhoyoko SA (2017), Jakarta socio-cultural ecology: a sustainable architecture concept in urban neighbourhood Sigit. IOP Conf. Series: Earth and Environmental Science 109, 1-9. https://doi.org/10.1088/1755$1315 /$

[6] Mutaqi AS (2018), Architecture Studio Learning: Strategy to Achieve Architects Competence. SHS Web of Conferences, 41(04004), 1-8.

[7] Zimmermann O, Wegmann L, Koziolek H \& Goldschmidt T (2015), Architectural Decision Guidance Across Projects - Problem Space Modeling, Decision Backlog Management and Cloud Computing Knowledge. 2015 12th Working IEEE/IFIP Conference on
Software

Architecture

$85-94$ https://doi.org/10.1109/WICSA.2015.29

[8] Hohpe G, Ozkaya I, Zdun U \& Zimmermann O (2016), The Software Architect 's Role in the Digital Age. IEEE Software 33(6), 30-39.

https://doi.org/doi.ieeecomputersociety.org/10.1109/MS.2016.137

[9] Amos-Abanyie S, Ayebeng Botchway E \& Kwofie TE (2014), The Relationship between Level of Architect's Professional Competencies and Client Satisfaction Level. Engineering Management Research 3(2), 10-19. https://doi.org/10.5539/emr.v3n2p10

[10] Davies P (2006), Exploratory Research. The SAGE Dictionary of Social Research Methods. https://doi.org/10.4135/9780857020116

[11] Fios F, Sasmoko \& Gea AA (2016), Neuro-Research Method: A Synthesis Between Hermeneutics and Positivism. Advanced $\begin{array}{lll}\text { Science } & \text { Letters } & \text { 22(9), }\end{array}$ https://doi.org/10.1166/as1.2016.7565

[12] Sandelowski M (2000), Combining qualitative and quantitative sampling, data collection, and analysis techniques in mixed-method studies. Research in Nursing \& Health 23(3), 246-255. https://doi.org/10.1002/1098-240x(200006)23:3<246::aidnur9>3.0.co;2-h

[13] Sasmoko, Ying Y (2015), Construct Validity in NeuroResearch. Advanced Science Letters 21(7), 2438-2441. https://doi.org/10.1166/asl.2015.6301

[14] Obralić A \& FuadCatovic (2016), The Impact of Personal Characteristics of Architects on their Architectural Work. International Journal of Learning \& Development 6(1), 42-52.

[15] Korn Ferry International (2016), Leadership ${ }^{T M}$ Architect technical manual. 